\title{
Influence of Work Life Balance (WLB) on Organisational Performance
}

\author{
A. Shamim Banu, G. Sundharavadivel
}

\begin{abstract}
This empirical study was aimed to explore the impact of work life balance factors on perception towards organisational performance of IT/ITES employees residing in Chennai city. This study was adopted empirical and exploratory research design to gather primary information and perception of IT/ITES employees with the help of structured questionnaire and survey method. The total sample of two hundred was finalized for the present study by adopting non-probability convenience sampling technique. The empirical evidences prove that family support, working environment, organisational climate and organisational commitment have significant and positive influence on perception towards organisational performance of IT/ITES Employees.
\end{abstract}

Keywords: Work Life Balance, IT/ITES, Organisational Performance, Family Support and Working Environment.

\section{INTRODUCTION}

$\mathrm{T}$ oday's industrial environment was highly competitive and dynamic in nature. There many industries are greatly undergoing tremendous change due to the growth of technological and economical changes in the Country. There are many factors influencing the organisational success rate in hyper competitive and dynamic market in India (Balaji et al., 2018). The opportunities are high and expectations are also high for many industries like, IT/ITES industry. The employees working in these type of IT/ITES companies are failed to maintain their work life balance due to occupational and familial stressors in their professional life (Krupanandhan, H., \& Kumar, C. P. (2018). The work life imbalance among employees has higher influence on the organizational performance of these companies. This present study aims to explore the phenomenon of work life balance factors influence on organisational performance of IT/ITES employees.

\section{REVIEW OF LITERATURE}

Balaji (2014) discussed the importance and role work life balance for women employees in information technology sector. The author was highlighted the role of work-family conflict and family-work conflict are the major factors need to addressed by every companies to enhance the productivity of the employees.

Revised Manuscript Received on December 05, 2019.

* Correspondence Author

A. Shamim Banu*, PhD Research Scholar, Department of Adult \& Continuing Education, School of Social Sciences, University of Madras, Chennai, India. Email: ashamimbanu@gmail.com

Dr. G. Sundharavadivel, Professor, Department of Adult \& Continuing Education, School of Social Sciences, University of Madras, Chennai, India
Jennifer Smith and Dianne Gardner (2007) examined the factors contributing for the betterment of work life balance of young and aged employees. The researcher conducted hypothetical study to examine the differences in the age group based on their work life balance perception and result indicates that aged employees have better work life balance as compared to young age employees.

Beauregard and Henry (2009) investigated the linkage between the WLB and organisational performance of employees of various business firms. The researcher found that WLB have significant influence on organisational performance. Job level and managerial support are the major factors determines the work life balance on these firms.

Scholarios and Marks (2004) conducted an exploratory study to understand the role of work life balance among software developers to examine their nature of attitude. The result indicates that negative spillover from software workers significant role in attitude towards work environment and positive spillover leads to higher organisational attachment and commitment.

Rukmani et.al, (2010) studied the role of leadership styles on organisational performance of IT employees in Tamil Nadu. The result indicates that transformational leadership style has significant impact on the organisational performance in Information Technology industry.

\section{STATEMENT OF THE PROBLEM}

In today's industrial environment, IT/ITES employees are exposed to job and family related stressors in their professional life. Due to several consequences and reasons maintaining the work life balance become more difficult and complex in today's technological environment. The excessive work load, time line for targets, not spending quality time with family members and many other reasons work life imbalance was prevailing among today's generation of IT/ITES employees. This work life Imbalance facilitates the lack of organisational performance. So, this present study aims to bring out the factors contributing the organisational performance among IT/ITES employees in Chennai city.

\section{RESEARCH OBJECTIVES OF THE STUDY}

1. To study the influence work life balance factors on organisational performance of IT/ITES employees in Chennai city.

\section{Published By:}




\section{RESEARCH METHODOLOGY}

The study adopted exploratory and diagnostic research design and primary data collection method was adopted to collect the perception of IT/ITES employees on work life balance and organizational performance perception in the Chennai city. The structured questionnaire with three sections was finalized to gather the primary information by adopting survey method of data collection. The collected were subjected data analysis using SPSS version 17.0 and statistical tools such as, percentage analysis and multiple regression analysis has been applied to draw the meaningful answers to the research objectives.

\section{RESULTS AND DISCUSSION}

The primary data collected from IT/ITES employees are subjected to data analysis and interpretation. The personal profile of the respondents are tabulated and inferred in Table.1.

Table 1: Personal Profile of the Respondents

\begin{tabular}{|c|c|c|}
\hline $\begin{array}{l}\text { Personal Profile }[\text { Sample Size }(N)= \\
200]\end{array}$ & Frequency & Percentage \\
\hline
\end{tabular}

Table 1 indicates that majority of respondents are Males (54\%), IT employees (60\%), aged less than 35 years $(84 \%)$, posses work experience of below five years $(87 \%)$ and earning annual income of less than Rs. 2, 00,000 (64\%). Majority of the respondents are hailing from nuclear families $(91 \%)$ and married $(73 \%)$ employees.

\begin{tabular}{|c|c|c|}
\hline $\begin{array}{l}\text { Personal Profile }[\text { Sample Size }(\mathbf{N})= \\
\text { 200] }\end{array}$ & Frequency & Percentage \\
\hline IT & 120 & $60 \%$ \\
\hline ITES & 80 & $40 \%$ \\
\hline \multicolumn{3}{|l|}{ Age (In Years) } \\
\hline Less Than 35 & 168 & $84 \%$ \\
\hline More than 35 & 32 & $16 \%$ \\
\hline \multicolumn{3}{|l|}{ Work Experience (In Years) } \\
\hline Below 5 Years & 174 & $87 \%$ \\
\hline Above 15 Years & 26 & $13 \%$ \\
\hline \multicolumn{3}{|l|}{ Annual Income (In Rs.) } \\
\hline Below Rs.2 Lakhs & 128 & $64 \%$ \\
\hline Rs.2 Lakhs - Rs.5 Lakhs & 48 & $24 \%$ \\
\hline Above 5 Lakhs & 24 & $12 \%$ \\
\hline \multicolumn{3}{|l|}{ Marital Status } \\
\hline Married & 144 & \\
\hline Unmarried & 54 & $27 \%$ \\
\hline \multicolumn{3}{|l|}{ Nature of Family } \\
\hline Nuclear & 182 & $91 \%$ \\
\hline Joint & 18 & $09 \%$ \\
\hline
\end{tabular}

The multiple linear regression analysis has been applied to explore the influence of work life balance factors on total organisational performance perception of IT/ITES employees in the study area. The empirical evidences are tabulated and presented in Table 2.

Table 2: Influence of Work Life Balance Factors on Organisational Performance of IT/ITES employees

\begin{tabular}{|c|c|c|c|c|c|c|c|c|}
\hline $\begin{array}{c}\text { Dependent } \\
\text { Variable }\end{array}$ & $\begin{array}{l}\text { Significant } \\
\text { Predictors }\end{array}$ & Mean (SD) & $\begin{array}{l}\text { F-Val } \\
\text { ue }\end{array}$ & $\mathbf{R}$ & $\mathbf{R}^{2}$ & $\begin{array}{c}\text { Adju } \\
\text { sted } \\
\mathbf{R}^{2}\end{array}$ & $\beta$ (t-Value) & Sig. \\
\hline \multirow{5}{*}{$\begin{array}{l}\text { Work Life } \\
\text { Balance }\end{array}$} & & $\begin{array}{l}22.487 \\
(2.112)\end{array}$ & $\begin{array}{l}45.12 \\
3 \\
(0.000 \\
)\end{array}$ & $\begin{array}{l}0.56 \\
7\end{array}$ & 0.321 & $\begin{array}{l}0.32 \\
0\end{array}$ & & \\
\hline & Family Support & $\begin{array}{l}20.234 \\
(2.423)\end{array}$ & & & & & $\begin{array}{c}0.307 \\
(6.432)\end{array}$ & $\begin{array}{c}<0.000 \\
* *\end{array}$ \\
\hline & $\begin{array}{l}\text { Working } \\
\text { Environment }\end{array}$ & $\begin{array}{l}18.456 \\
(3.211)\end{array}$ & & & & & $\begin{array}{c}0.241 \\
(4.001)\end{array}$ & $\begin{array}{c}<0.000 \\
* *\end{array}$ \\
\hline & $\begin{array}{l}\text { Organisational } \\
\text { Commitment }\end{array}$ & $\begin{array}{l}12.234 \\
(2.999)\end{array}$ & & & & & $\begin{array}{c}0.238 \\
(2.658)\end{array}$ & $\begin{array}{c}<0.005 \\
* *\end{array}$ \\
\hline & $\begin{array}{l}\text { Organisational } \\
\text { Climate }\end{array}$ & $\begin{array}{l}14.900 \\
(1.009)\end{array}$ & & & & & $\begin{array}{c}0.231 \\
(2.198)\end{array}$ & $\underset{* *}{<0.003}$ \\
\hline
\end{tabular}

Constant with $\mathbf{t}$ value of 9.872 at $\mathbf{P}$ Value of <0.001** - (Family Support, Working Environment, Organisational Climate and Organisational Commitment dimensions are s Significant Influencing the Work life balance of IT/ITES employees) - Overall Cronbach's Alpha Value $==0.821$ (34 items)

Notes: *** Significant @ 1\% level, *Significant @ 5\% Level. 
Table 2 reveals that OLS Model has a goodness of fit for multiple regression analysis and the linear combination of family support, working environment, organisational commitment, organisational climate on organisational performance, $\{\mathrm{F}=45.123, \mathrm{p}<0.001\}$. The multiple correlation co-efficient is 0.567 , indicating that $32 \%$ of the variance of the respondent's Organisational Performance in the order of influence. Family support, working environment, organisational commitment and organisational climate are significantly and positively influence organisational performance of the IT/ITES employees.

\section{IMPLICATIONS AND CONCLUSION}

This study proves that organisational performance perception of IT/ITES employees has been significantly and positively influenced by the work life balance factors such as, family support, working environment, organisational climate and organisational commitment. Family support was the major factor contributing the organisational performance perception. So, the IT/ITES employees are suggested to spend very good quality time with their family member to enhance the role of family support to have better work life balance and in turns which enhances the organisational performance perception of the IT/ITES employees.

The second most imperative factor affecting the organisational performance was working environment effectiveness. Therefore, IT/ITES companies are suggested to provide proper working environment and working conditions with sophisticated facilities to provide better work life balance to their human capital. The organisational climate and organizational commitment are also needs to be given focus for the purpose of enrichment in work life balance and organisational performance of IT/ITES employees. The policies of the company should be nurture to encourage the employee to put more efforts and commitment towards their job.

\section{REFERENCES}

1. Balaji, R. (2014). Work life balance of women employees. International Journal of Innovative.

2. Balaji, P., Behera, S., \& Kumar, A. (2018). Dimensionality and Antecedents of Quality of Work Life. Sumedha Journal of Management, 7(3), 22-28.

3. Beauregard, T. A., \& Henry, L. C. (2009). Making the link between work-life balance practices and organizational performance. Human resource management review, 19(1), 9-22.

4. Krupanandhan, H., \& Kumar, C. P. (2018). Exigency of Work-Life Balance Supportiveness among Employees of BPO Companies. Indian Journal of Human Relations, 52(2), 22-30.

5. Rukmani, K., Ramesh, M., \& Jayakrishnan, J. (2010). Effect of leadership styles on organizational effectiveness. European Journal of Social Sciences, 15(3), 365-369.

6. Scholarios, D., \& Marks, A. (2004). Work-life balance and the software worker. Human Resource Management Journal, 14(2), 54-74.

7. Smith, J., \& Gardner, D. (2007). Factors affecting employee use of work-life balance initiatives.

\section{AUTHORS PROFILE}

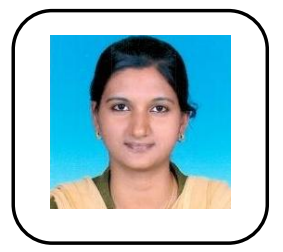

The name of First Author is Mrs.A.Shamim Banu.,M.B.A.,M.Phil. She is a full-time Ph.D Research Scholar at Department of Adult \& Continuing Education, University of Madras under the guidance of Professor Dr.Sundharavadive Department of Adult \& Continuing Education,
University of Madras. The author has Life-time membership in All India Council of Mass Education and Development (AICMED). She has published in the reputed and UGC approved journals. The author has Participated and presented a paper in the national conference titled" KNOWLEDGE MANAGEMENT THE PILLAR FOR INNOVATION AND SUSTAINABILITY, Organised by the school of business studies, Dr.MGR-Janaki college of arts and science for women, Chennai on September2018 and DEVELOPMENT OF WOMEN IN MODERN ERA AND WOMEN EMPOWERMENT IN INDIA, Organised by Aksheyaa College Of Arts and Science, Kanchipuram on January 2019. She has also Published paper in IMPACT: International Journal Of Research in Humanities, UGC approved Journal: 40893 titled “A STUDY ON MENTORING AS AN OD INITIATIVE IN IT COMPANY, CHENNAI” on September 2018 and International Journal Of Human Resource Management and Research(IJHRMR) UGC approved Journal, Paper Id: IJHRMRAPR20196 titled "A RELATIONSHIP BETWEEN WORK LIFE BALANCE AND JOB PERFORMANCE OF EMPLOYEES” on April 2019.

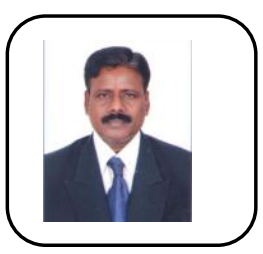

The name of Second Author is "Dr.Sundharavadivel". He is a "Professor" at Department of Adult \& Continuing Education, University of Madras with more than 15 years of Experience in the field of Adult and Continuing Education. The author is a rank holder in MA (Andragogy), did Ph.D. in Vocational Education from the University of Madras. He did his M.L.M, MBA and M.Phil. (Entrepreneurship) from M.K. University. The author completed M.S.W, M.Sc. (Yoga) from Annamalai University and PGDHRM from Pondicherry University. The author served as programme officer NSS from 2005 to 2010 and has presented papers in National and International seminar, Conferences and workshops. The author has also completed M.COM (Education Management). The author has received "AasiriyarSemmal" award from Thamizhaga Institute of Educational Research and Advancement (TIERA) on teacher's day, September 5th 2019 and "Best professor" award from ESN Publications on 28th September 2019. He has published in the reputed and UGC approved journals. 